\title{
The impact of international financial reporting standards on fund performance
}

\author{
Matthias Nnadi \\ Cranfield University, UK \\ Dmitrij Rubanov \\ Cranfield University, UK \\ Akunna Oledinma \\ University of Warwick, UK
}

\begin{abstract}
\section{Purpose}

This paper examines the effect of IFRS on the performance of UK investment closed-end trust funds with domestic equity focus using Carhart's Four-Factor model.

\section{Design/methodology/approach}

The paper is based on the Efficient Market Hypothesis, which argues that all available information is already included in the price of assets and therefore, investors cannot beat the market or generate abnormal returns.

\section{Findings}

The results show that on average UK investment trusts do not generate abnormal returns, nor is their performance persistent. Our study provides empirical evidence to supports the efficient market hypotheses, and provides proof that the adoption of IFRS has on average, a decreasing impact on the excess returns generated by UK investment trusts.
\end{abstract}

\section{Originality/Value}

The findings of the paper have business policy implications for investment trust in the UK.

Keywords: investment trust; abnormal return; performance; persistence; IFRS; closed-end

Paper type: Research paper 


\section{Introduction}

Some studies consider the assessment of performance in mutual funds as a test of the Efficient Market Hypothesis (EMH), which assumes, that all information is already included in the prices of assets and that investors cannot beat the market or generate abnormal returns (Fama, 1970). Therefore, finding evidence of performance persistence would suggest, that the market is not semi-strong efficient. On the other hand, any evidence of no persistence in fund performance would support the EMH and suggest that abnormal returns generated by fund managers are due to luck and not to skill (Fama, 1970). Some studies (Treynor and Mazuy, 1966; Jensen, 1968; Elton et al., 1996; Phelps and Detzel, 1997; and Henriksson, 1984) find no evidence of persistence in abnormal fund returns over various periods. This implies that past performance do not predict future performance. On the other hand, studies by Grossman and Stiglitz (1980), Hendricks et al (1993) find evidence of persistence of fund performance suggesting that fund managers have the ability to generate abnormal returns. Though Angelidis et al. (2013) observe that mutual fund managers are evaluated against the benchmark stated in the fund's prospectus; therefore their performance is guided by the nature of that benchmark.

Some other studies such as Goetzmann and Ibbotson (1994), Grinblatt et al (1995), Gruber (1996), Carhart (1997), Daniel et al. (1997) and Wermers (2000) find persistence of performance over short periods of time. Good performance can at least partly be attributed to managerial skill, though on average, funds generate negative abnormal returns. Others have examined whether companies that use local research offices show superior investment performance than others (Hung, 2001). However, Carhart (1997) shows that persistence of fund performance among top performers disappears and remains only in low performers, where it probably arises from high transaction expenses. This is because fund performance is more strongly affected by the fund manager's ability to minimize downside losses rather than selecting outperforming portfolio particularly in buyouts rather than venture capitals (Buchner et al., 2016).

Most of the aforementioned studies however focus on open-end funds (Berk and Green, 2004; Bangassa et al, 2012) and only a few studies evaluate the performance or persistence of closedend funds which differ from open-end funds. Few studies have examined the performance and persistence of closed-end funds in the UK, particularly the performance of UK investment trusts. Bal and Leger (1996), Leger (1997), Hooper et al (2006), Allen and Tan (1999) and 
Bangassa et al (2012) present various findings on the persistence in performance of UK closedend funds. Our study extends the literature on closed-end funds, particularly UK investment trusts by investigating the performance of UK closed-end funds over the more recent period from 1997 to 2014. Unlike open-end funds, closed-end funds sell a fixed amount of shares, thus managers of closed-end funds do not have to deal with unexpected fund inflows in a period with few investment opportunities. As there are significant differences between opened and closed ends funds, and with differing implications for investors, results of previous studies on the open-end fund industry cannot be applied to the closed-end fund industry.

In theory, fund managers possess certain expertise, which allow them to continuously generate abnormal returns and most investors are willing to invest on the basis funds' prior performance. In addition to testing if UK investment trusts can generate persistent abnormal returns, the paper also investigates whether the adoption of International Financial Reporting Standards (IFRS) across the European Union (EU) in 2005 have significant effect on the performance of investment funds. Following the adoption of International Financial Reporting Standards (IFRS) public companies have to disclose more information about their financial position making it easier for investors to make investment decisions. On the other hand, the additional information becomes available for all market participants, making the markets more efficient and therefore harder to generate abnormal returns.

Advocates of IFRS argue that a uniform system of financial reporting will enhance comparability of financial statements, reduce information asymmetry and therefore attract foreign investors (DeFond et al, 2011 and Bielstein, et al, 2007). Therefore the EU wide adoption of IFRS in 2005 should improve the financial statement comparability leading to increase in investments and improved performance of the UK investment trust funds. Improved comparability and transparency of financial statements will be attractive to investment trust fund investors as they are likely to base their investment decisions on the basis of such comparable and detailed analysis of the financial statements (DeFund et al, 2011). The adoption of IFRS in itself will not improve fund performance except if it is faithfully implemented (IASB, 2008; Henry, 2008). However, the UK has a strong enforcement rate (Leuz et al, 2003), including IFRS implementation which has a subsequent positive impact on performance of investment funds. DeFund et al (2011) confirm that IFRS adoption results in a greater increase in mutual fund investment in countries, such as the UK, with strong 
implementation credibility. The current study therefore expands the IFRS literature by analysing its impact on UK investment funds.

However, there is a gap in the literature on studies examining the effect of IFRS on investment fund performance. This is because several studies on IFRS focus on other aspects and functionality of the financial market, such as accuracy of analysts' forecasts (Jiao et al, 2012), foreign investment (Gordon et al, 2012; Nnadi and Sooberayen, 2015), information content of earnings announcement (Landsman et al, 2012), foreign and home ownership bias of mutual funds (deFond et al, 2011; Covrig et al, 2007). Other studies examine whether IFRS affects persistence of earnings. For example, Doukakis (2010) examines whether the mandatory adoption of IFRS has an impact on the information content of earnings components for future profitability, and the results suggest that IFRS measurement and reporting guidelines do not seem to improve the persistence of earnings and earnings components. To the best of our knowledge, this is first study to investigate the impact of IFRS on the performance of UK investment funds. In theory, the adoption of IFRS should make the UK market more efficient and therefore more difficult for fund managers to generate abnormal returns.

Most studies on mutual funds argue that due to the efficient market hypothesis, mutual funds usually do not outperform their pre-set benchmark, nor are their performance persistent (Berks and Green, 2004; Hooper et al, 2006). This implies that positive performance is most commonly based on luck and not the manager's skill-set. Consequently, Berk and Green (2004) propose that performance is not persistent and investments with active managers do not outperform the passive benchmarks on average. However, the lack of persistence in returns does not imply that managerial skills and ability are unrewarded or that gathering information about performance is socially wasteful.

We therefore investigate if the mandatory adoption of IFRS had any influence on the performance of UK domestic Investment trusts.

Hence, this paper addresses the following three questions:

1. Do UK domestic investment trusts generate abnormal returns?

2. Is there any persistence in UK domestic investment trust performance?

3. Does the adoption of IFRS have any influence on UK domestic investment trust performance? 
The rest of the paper is organised as follows: Section 2 is the literature review, Section 3 is the development of research hypotheses, and Section 4 describes the data used in the study and Section 5 is the methodology, Section 6 is the presentation and discussion of results, Section 7 is the summary of findings and Section 8 is the conclusion.

\section{Literature review}

The main difference between closed-end and open-end funds, is that closed-end funds collect a limited amount of capital through issuing a fixed amount of shares, which are then traded on a public stock exchange and over-the-counter. On the other hand, open-end funds are traded over-the-counter and continue to receive capital inflows throughout their lifetime. Anderson et al (1996) explain that the price of closed-end fund shares is similar to other traded securities which are determined by supply and demand, investors' perception and the state of the economy. This implies that their shares can trade below or above their Net Asset Value. On the contrary, open-end fund shares trade at their Net Asset Value including loading charges.

Several studies have been undertaken to examine performance and persistence of funds. Grinblatt and Titman (1992) analyse past performance of mutual funds and identify significantly higher consistency of performance of losers rather than winners. Their results show evidence that the difference in performance of funds persists over time and such persistence is consistent with the fund manager's ability to outperform the benchmark. Such benchmarks are usually set out in the fund's prospectus (Angelidis et al. (2013). Results in fund persistence have been mixed. Hendricks et al (1993) find that in the period from 1974 to 1988, the relative performance of growth-oriented mutual funds persists in the short term, although they find the most significant evidence over a one-year evaluation period. Malkiel (1995) investigates the persistence in performance from 1971 to 1991 and finds no persistence in performance and concludes that previous findings of persistence in performance could be attributed to the time period evaluated.

Study by Carhart (1997) finds no evidence that persistence in performance can be attributed to the skill and experience of fund managers, but rather the worst-return mutual funds experience persistence in performance. Zheng (1999) shows that funds that outperform in a period subsequently perform significantly better than the funds that underperformed in the previous 
period and therefore implies that winning funds outperform the market in the long term. Anderson et al. (1996) argue that managers of closed-end funds focus better on long term performance than short term market fluctuations. This is because closed-end fund managers do not deal with unexpected fund inflows or hold cash reserves which allow investors to withdraw money like open-end fund managers. In fact, Kryzanowski and Mohebshahedin (2016) suggest that closed-end funds with higher board ownerships are better aligned with shareholders' interests. Therefore, closed-end fund managers can better focus on available opportunities in the market, whilst open-end fund managers might receive an unexpected fund inflow when there are fewer opportunities on the market.

The differences between open-end and closed-end funds are based on their trading strategies. For instance, closed-end funds are less restricted than open-end funds, and the latter can issue and redeem shares throughout their lifetime. To be able to redeem shares at any time, openend funds have to maintain a specific amount of their capital in cash, which restricts their investment opportunities. This can be challenging given the different investment opportunities in the market. Bers and Madura (2000) explain the problem of investment timing for open-end fund managers, since investors usually invest more capital, when the market is bearish and redeem capital when the market is bullish, which forces the fund managers to use adverse investment timing strategies. In this regards, Gupta and Jithendranathan, (2012) argue that that investors base their investment decisions on the past performance of funds, and that retail investors prefer less risky investments compared to wholesale investors. Therefore, closed-end funds face lower transaction costs, since they are not overwhelmed with unexpected cash inflows or redemption requests. Additionally, open-end funds can issue only one class of shares, which is common stock, while closed-end funds can issue preferred and common stock or leverage through debt issue (Bers and Madura, 2000).

Bal and Leger (1996) analysed the performance of 92 UK investment trusts from 1975 to 1993 using the Sharpe, Jensen and Treynor measures. Their results portray two distinctive findings. First, on average funds underperformed compared to the market portfolio even without correcting for transaction costs. Second, funds ranked by the Sharpe measure portray significant intertemporal persistence in performance. These results are corroborated by Leger (1997) who finds very weak performance with little persistence in measures of "timing" and "selectivity". The results show negative timing performance for approximately one third of investment trusts in the sample, though the patterns of significant selectivity and timing tend 
to reverse after the first period. Bangassa et al (2012) examine the selectivity and timing performance of 218 UK investment trusts from July 1981 to June 2009 find weak evidence for selectivity and timing abilities, but interestingly the GJR-GARCH-M method reverses their results, providing evidence for selectivity ability for international funds and timing ability for domestic funds. Fama and French (2010) analyse the aggregate returns of a sample of 3156 actively managed mutual funds between 1984 and 2006 using the CAPM, Three-Factor model and the Carhart Four-Factor model. Their analysis shows, that after deducting expenses, the funds in their sample on average underperform the benchmark index. These studies provide an overall evidence of diverse results between international and domestic funds.

The adoption of International Financial Reporting Standards (IFRS) around the world and in the European Union (EU) represents the largest change of accounting regulations of the past decade. In 2002, the European Union adopted the IAS Regulation, thereby requiring its entire member states to mandatory adopt and follow the rules of IFRS starting from January 1st, 2005. This event required more than 7,000 public companies to switch from their domestic accounting standards to IFRS and triggered speculations on the impact of IFRS on the amount of information available to financial analysts and consequently on investor's behaviour (Byard et al., 2011). According to Ball (2006), the adoption of IFRS can potentially increase crossborder comparability, accounting report transparency, as well as reduce information costs and asymmetry, and with a consequent increase on the liquidity and efficiency of markets. These benefits rely on the assumption that the mandatory IFRS adoption increases the comparability of published accounting information across countries and provides superior information to market participants (Horton et al., 2013; Nnadi and Soobaroyen, 2015).

Additionally, Horton et al. (2013) argue that the mandatory IFRS adoption has a decreasing effect on forecast errors for firms that mandatorily adopted the IFRS compared to the forecast errors of other firms. They conclude that IFRS improves the quality of information intermediation in capital markets as well as the quality of information and comparability of accounting reports. The adoption of IFRS also stimulates the volume of trading. For instance, Brüggemann et al. (2010) examined the impact of IFRS adoption on cross-border equity investments of individual investors and find a significant increase in open market trading volume following the implementation of IFRS. These results suggest that the worldwide adoption of accounting standards enhances cross-border equity investments. 
Armstrong et al. (2010) investigated the reaction of the European Stock Market to events associated with the adoption of IFRS in the European Union. They find a more positive reaction for firms with lower information quality prior to the adoption and a less positive reaction for firms located in code law countries. This is due to investors' concerns over enforcement of IFRS in those countries. Overall, their findings suggest, that there are net benefits associated with the adoption of IFRS for European investors. Even in countries with overreaching government control such as China, the convergence to the IFRS has been reported as reducing earnings management (Ho et al, 2015; Nnadi, 2015). Florou and Pope (2012) provide evidence that institutional investments increased in firms that adopt the IFRS, which can be explained by an increase of investors' confidence due to the positive impact of the adoption of IFRS. Although such impacts vary across different European countries, for example, firms in countries with stronger law enforcement systems benefit from IFRS adoption more than the ones in countries with weaker enforcement systems (Pope and McLeay, 2011).

\section{Development of research hypotheses}

The current study is underpinned by the Efficient Market Hypothesis, we argue that with the additional information that becomes publically available on public companies, the market should become more efficient thus more difficult for fund managers to generate abnormal returns. The majority of previous research undertaken to investigate the performance and persistence in performance of mutual funds conclude, that there is little evidence of persistence of fund performance, additionally, on average mutual funds do not generate significant abnormal returns.

The aim of this paper is to expand the existing literature on closed-end funds by examining the persistence in performance of UK investment trusts that allocate their capital mainly in UK domestic securities. In addition, we investigate whether the adoption of IFRS across the European Union, has any impact on investment trust performance. The adoption of IFRS makes more information available about public companies and makes it easier for fund managers to assess the financial performance of a company, and therefore make more profitable investment decisions and generate higher returns. However, the EMH suggests, that all information is already included in the price of a security and that security prices follow a random walk (Fama, 
1970). Therefore, in a highly efficient UK market, fund managers should not be able to generate abnormal returns. Therefore the first hypothesis is:

\section{H1: Closed-end UK investment trusts do not generate abnormal returns}

According to the EMH, security prices follow a random walk; therefore past returns cannot be used to predict future returns. Thus, abnormal returns generated by fund managers are due to luck and not to skill. Therefore, there should be no persistence in UK investment trust performance. Our paper investigates if there is any persistence in UK investment trust performance and our second hypothesis is:

\section{H2: There is no persistence in UK closed-end investment trust performance}

Since January 2005, public companies incorporated in the UK are mandatorily required to prepare their financial statements in line with the IFRS. The EU wide adoption of IFRS aims to increase, unify and internationalise the information disclosed by public companies. Thus, the UK market already being a very regulated and developed market should even become more efficient. With more information being available about UK companies, investment trusts companies are expected to find it more difficult to generate abnormal returns. Thus, we test if the adoption of IFRS has an influence on UK investment trust performance and our third hypothesis therefore is:

H3: The adoption of Accounting Standards has no significant influence on UK closed-end investment trust performance

\section{Data}

Two datasets were used to analyse the UK investment trust performance - data on the investment trusts and benchmark data for the four factors (Small-cap stocks minus large-cap stocks, High book-to-market stocks minus low book-to-market stocks, Market risk premium factor, Momentum factor), used in the Carhart Four-Factor model. The fund dataset used in this paper consists of 119 UK domestic investment trust returns from FTSE 350 index portfolios dating from January 1997 to December 2014 which are collected from DataStream.

To include the investment trust in the sample, the trust must not only be incorporated in the UK, but also be primarily invested in UK equities. This method is used because only these funds are appropriate to be measured against UK risk free rates and the Carhart Four-factors 
computed from FTSE 350 Index portfolios thus leaving 119 domestic investment trusts with UK domestic equity focus.

The final step of the data collection procedure involves obtaining the monthly net asset values (NAV) for the evaluation period from Datastream. This research uses the net asset values instead of the share price because the price of investment trust shares is determined by supply and demand as well as investors' perception. Therefore their shares often trade at a discount to the actual value of their portfolio. The NAV which is based on the total value of shares in a fund's portfolio is therefore considered more appropriate to measure the funds' performance.

\section{Methodology}

This study evaluates the performance of 119 UK domestic investment trusts over six nonoverlapping three-year periods using panel data from January 1997 to December 2014 as presented in Table 1. Our method follows Bangassa et al (2012) and applies the Carhart FourFactor Model, which is built on the classic Capital Asset Pricing Model (CAPM) and the Fama and French Three-Factor model to measure fund performance.

\section{Table 1: Breakpoints between sub-periods}

The table below explains the breakpoints between the non-overlapping three-year sub-periods.
The reason for choosing three year sub-periods is to have enough observations for the regressions. Each sub-
period contains 36 monthly fund excess returns calculated from the funds' monthly Net Asset Values. The first
step in measuring performance is to calculate the funds returns in excess of the risk free rate (funds return in
excess of the risk free rate = excess return). For every sub-period the monthly fund excess returns were
calculated. After subtracting the risk-free rate, the excess returns of 119 UK domestic investment trusts were
regressed on the Carhart Four-factors .
\begin{tabular}{c|c|c|c|c|c} 
Jan $1997-$ & Jan $2000-$ & Jan $2003-$ & Jan $2006-$ & Jan $2009-$ & Jan $2012-$ \\
Dec 1999 & Dec 2002 & Dec 2005 & Dec 2008 & Dec 2011 & Dec 2014 \\
\hline $1^{\text {st }}$ sub-period & $2^{\text {nd }}$ sub-period & $3^{\text {rd }}$ sub-period & $4^{\text {th }}$ sub-period & $5^{\text {th }}$ sub-period & $6^{\text {th }}$ sub-period \\
\hline
\end{tabular}

Carhart Four-Factor model posits that firms with higher returns in one period tend to keep the same level of returns in the next period and it incorporates the momentum effect (Carhart, 1997). The Three-Factor model does not explain the momentum effect, which is one of its shortcomings. The momentum effect is the empirically observed tendency of strong performing stocks to outperform weak performing stocks in the next period (Jagadeesh and Titman, 1993). The momentum factor developed by Carhart (1997) is an extension of the Three-Factor model and captures the short term continuation effect of the funds, and its calculated as the difference 
of a portfolio with high momentum stocks and a portfolio with low momentum stocks. The monthly yield of the three months UK Treasury bill represents the risk-free rate and the four factors were constructed based on the 350 firms of the FTSE 350 index (Gregory et al., 2013). We test for heteroscedasticity using Breusch-Pagan and the Breusch-Godfrey test for autocorrelation and our regression equation is as follows:

$R_{t}-R_{f}=\alpha_{t}+\beta_{1} R M R F_{t}+\beta_{2} S M B_{t}+\beta_{3} H M L_{t}+\beta_{4} M O M_{t}+\varepsilon_{t} \ldots \ldots \ldots \ldots \ldots \ldots \ldots \ldots . \ldots 1$

where:

$\boldsymbol{S M B}=$ Small-cap stocks minus large-cap stocks

$\boldsymbol{H M L}=$ High book-to-market stocks minus low book-to-market stocks

$\boldsymbol{R} \boldsymbol{M} \boldsymbol{R} \boldsymbol{F}=$ Market risk premium factor

$\mathbf{M O M}=$ Momentum factor

$\boldsymbol{\varepsilon}_{\boldsymbol{t}}=$ Error term

A high momentum factor coefficient $\mathrm{m}_{\mathrm{i}}$ indicates that a fund invested more in high momentum stocks. The monthly NAV of each of the 119 funds in the sample are first converted into monthly investment trust returns $\left(\mathrm{R}_{\mathrm{i}}\right)$. Then after subtracting the risk free rate $\left(\mathrm{R}_{\mathrm{f}}\right)$ from the investment trust return, we obtain the fund's excess return, which represents the funds returns in excess of the risk-free rate. Each fund's monthly excess return is then regressed on the Carhart's Four-Factor model. The Carhart Four-Factor model is used to calculate the abnormal returns of 119 UK investment trusts. The FTSE 350 Index is used as the benchmark. Our period of investigation is from January 1997 to December 2014 and is divided into six three-year (36 months) sub-periods which allows to have sufficient observations for the regressions using monthly investment trust returns calculated from NAV.

Similar to Agarwal and Naik (2000), Malkiel and Saha (2005), and Eling (2009), we classify fund performance persistence as winners and losers using a contingency table. While the winner funds are those performing better than the benchmark of the FTSE 350 investment funds, the losers are funds performing worse than the funds benchmark respectively. Thus using the NAV which is based on the total value of shares in a fund's portfolio, we classify a fund as winner if it has a higher return in a specific period than the median return of all FTSE 
350 funds within the period. The result si presented in Table 2 below and shows that there are more losers in periods $1,3,5$ and 6 respectively.

\section{Table 2: Winner and loser funds for the sub-periods}

The table summarises the winner and losers funds in the sample of 119 UK domestic investment trusts for each of the six three- year sub-periods. Loser fund are those that generate returns below those of the FTSE 350 benchmark, while winner funds generate returns above those of the FTSE 350 benchmark.

\begin{tabular}{|l|l|l|}
\hline Sub-periods & Winners & Losers \\
\hline $1997-1999$ & $28(23.5 \%)$ & $91(76.5 \%)$ \\
\hline $2000-2002$ & $75(63 \%)$ & $44(37 \%)$ \\
\hline $2003-2005$ & $49(41.2 \%)$ & $70(58.8 \%)$ \\
\hline $2006-2008$ & $72(60.5 \%)$ & $47(39.5 \%)$ \\
\hline $2009-2011$ & $42(35.3 \%)$ & $77(64.7 \%)$ \\
\hline $2012-2014$ & $43(36.1 \%)$ & $76(63.9 \%)$ \\
\hline
\end{tabular}

\section{Testing the influence of IFRS on UK investment trust performance}

We use modified version of the Carhart Four-Factor model to test if the adoption of IFRS has an impact on UK investment trust performance by using a dummy variable - AAS, as a proxy for the adoption of accounting standards. This approach is consistent with Bangassa et al (2012) which apply the modified form of the Carhart Four-Factor model in capturing the selectivity and timing performance effects of UK trust investments. The use of dummy variable in capturing the effect of IFRS impact on performance is very common in accounting literature such as in the impact of IFRS regulatory change on FDI (Gordon et al, 2012); IFRS on regional investments (Nnadi and Sooberayen, 2015); and IFRS on corporate governance (Judge et al (2010). However, to ensure that our model does not just capture a temporary shift in the regime caused by the financial crisis, we create a dummy CRISIS to disentangle the effect of IFRS from the financial crisis. This approach is similar to Kontonikas et al (2013) which applied a dummy variable to capture the effect of the financial crisis on state dependence during the sudden rise in the federal fund rate (FFR) in the US.

The rationale underlining this test is that the EU wide adoption of accounting standards has increased reporting transparency, reduced information asymmetry and thereby increased the efficiency and competitiveness of markets. The EMH holds that more efficient market would 
make it more difficult for fund managers to generate positive abnormal returns (Horton et al., 2013). Our regression is run from 1997 to 2014 with the baseline date being $1^{\text {st }}$ of January 2005, the date of mandatory adoption of IFRS, and is stated as:

$R_{t}-R_{f}=\alpha_{t}+\beta_{1} R M R F_{\mathrm{t}}+\beta_{2} S M B_{t}+\beta_{3} H M L_{t}+\beta_{4} M O M_{t}+\beta_{5} A A S_{t}+\beta_{6} C R I S I S_{t}+\varepsilon_{t} \ldots \ldots \ldots .2$

where:

$\boldsymbol{A A S}$ is a dummy variable for the Adoption of Accounting $\underline{\text { Standards }}(0=$ from January 1997 to December 2004; 1 = from January 2005 to December 2014). The CRISIS dummy takes a value of 1 during 2007 and 2008 and zero otherwise. All other variables are as in Carhart's Four-Factor model.

A positive coefficient indicates that the adoption of IFRS increased the excess fund returns, while a negative coefficient indicates that the adoption of accounting standards has a negative effect on funds excess returns. If the CRISIS dummy variable is negative and significant, then we can conclude that it is indeed the effect of regime change.

\section{Robustness check}

To check test the reliability of our result on the impact of the AAS variable, which is used as a proxy for the adoption of accounting standards, we re-estimate our model using observations until end of 2006 prior to the financial crisis period. A negative effect will confirm that the IFRS regime has a negative effect on the performance of the funds.

\section{Presentation and discussion of results}

\section{Performance Results}

Table 3 summarizes the descriptive statistics for the monthly excess returns for each of the six sub-periods. 


\section{Table 3: Excess Return Descriptive Statistics}

The table below presents the descriptive statistics of the monthly excess fund returns for each of the six subperiods. The excess returns represent the funds monthly returns in excess of the risk free rate and are derived from 119 UK domestic equity investment trusts from January 1997 to December 2014. In order to measure the performance of investment trusts. The Excess Returns of funds are computed in the following as:

$$
\text { Excess Return }=\mathrm{R}_{\mathrm{t}}-\mathrm{r}_{\mathrm{ft}}
$$

where $R_{t}$ is the return of fund at time $t, r_{f t}$ is the UK risk free rate at time $t$. Each sub-period contains the data for 119 funds with each 36 monthly excess returns, totalling 4,284 observations per sub-period. The average values at the bottom of the table represent the average across all six sub-periods.

\begin{tabular}{|c|c|c|c|c|c|c|c|}
\hline Variable & Period & $\begin{array}{c}\text { Mean } \\
(\%)\end{array}$ & $\begin{array}{c}\text { Median } \\
(\%)\end{array}$ & $\begin{array}{c}\text { Minimum } \\
(\%)\end{array}$ & $\begin{array}{c}\text { Maximum } \\
(\%)\end{array}$ & $\begin{array}{c}\text { Standard } \\
\text { Deviation } \\
(\%)\end{array}$ & No of Obs. \\
\hline \multirow{6}{*}{$\begin{array}{l}\text { Excess } \\
\text { Return }\end{array}$} & $\begin{array}{c}1997- \\
1999\end{array}$ & 1.005 & 0.877 & -42.621 & 66.238 & 6.396 & 4,284 \\
\hline & $\begin{array}{c}2000- \\
2002\end{array}$ & -1.368 & -0.695 & -37.164 & 50.373 & 7.147 & 4,284 \\
\hline & $\begin{array}{l}2003- \\
2005\end{array}$ & 1.263 & 1.095 & -27.386 & 28.452 & 4.183 & 4,284 \\
\hline & $\begin{array}{c}2006- \\
2008\end{array}$ & -0.857 & -0.081 & -49.703 & 26.529 & 5.815 & 4,284 \\
\hline & $\begin{array}{c}2009- \\
2011\end{array}$ & 0.888 & 0.747 & -36.633 & 28.095 & 5.637 & 4,284 \\
\hline & $\begin{array}{r}2012- \\
2014\end{array}$ & 0.918 & 0.686 & -22.515 & 87.062 & 4.146 & 4,284 \\
\hline Average & $\begin{array}{c}1997- \\
2014\end{array}$ & 0.308 & 0.438 & -36.004 & 59.193 & 5.554 & 25,704 \\
\hline
\end{tabular}

The mean monthly fund excess returns for each of the six periods shows that in four out of six periods the funds on average are able to generate returns above those of the risk free rate between $0.89 \%$ and $1.26 \%$. In two out of six periods, the mean monthly excess returns are below the returns of the risk-free rate and negative with values of $-0.86 \%$ and $-1.37 \%$. However, the average standard deviation of $5.55 \%$ across all periods as well as the minimum and maximum values indicates that there is dispersion in funds excess returns across the sample period. The next step in measuring performance is to regress the obtained excess fund returns on the Carhart's Four-Factor model. Table 4 summarizes the descriptive statistics of the $\mathrm{R}^{2}$ values obtained from the Carhart's Four-Factor regression models for each of the six subperiods rounded to three decimals. 
The table below shows the descriptive statistics of the $\mathrm{R}^{2}$ values obtained from regressing the excess returns of 119 UK investment trusts on the four factors of Carhart's Four-Factor model over the period from January 1997 to December 2014 in the following way:

$$
R_{t}-R_{f}=\alpha_{t}+\beta_{1} R M R F_{t}+\beta_{2} S M B_{t}+\beta_{3} H M L_{t}+\beta_{4} M O M_{t}+\varepsilon_{t}
$$

The values at the bottom of the table represent the average across all six sub-periods.

\begin{tabular}{|c|c|c|c|c|c|c|c|}
\hline Variable & Period & $\begin{array}{c}\text { Mean } \\
(\%)\end{array}$ & $\begin{array}{c}\text { Median } \\
(\%)\end{array}$ & $\begin{array}{c}\text { Minimum } \\
(\%)\end{array}$ & $\begin{array}{c}\text { Maximum } \\
(\%)\end{array}$ & $\begin{array}{c}\text { Standard } \\
\text { Deviation } \\
(\%)\end{array}$ & No of Obs. \\
\hline \multirow{6}{*}{$\mathbf{R}^{2}$} & $\begin{array}{c}1997- \\
1999\end{array}$ & 69.351 & 75.870 & 24.155 & 90.349 & 15.829 & 119 \\
\hline & $\begin{array}{c}2000- \\
2002\end{array}$ & 74.720 & 78.968 & 25.745 & 93.732 & 15.716 & 119 \\
\hline & $\begin{array}{c}2003- \\
2005\end{array}$ & 69.077 & 75.747 & 22.032 & 95.622 & 19.346 & 119 \\
\hline & $\begin{array}{l}2006- \\
2008\end{array}$ & 69.398 & 74.892 & 20.998 & 95.363 & 19.025 & 119 \\
\hline & $\begin{array}{c}2009- \\
2011\end{array}$ & 71.923 & 77.958 & 22.947 & 92.025 & 16.880 & 119 \\
\hline & $\begin{array}{l}2012- \\
2014\end{array}$ & 67.654 & 72.490 & 19.538 & 90.240 & 18.367 & 119 \\
\hline Average & $\begin{array}{l}1997- \\
2014\end{array}$ & 70.354 & 75.988 & 22.569 & 92.889 & 17.527 & 714 \\
\hline
\end{tabular}

The estimates for the $\mathrm{R}^{2}$ values across all periods range between $19.54 \%$ and $95.62 \%$. The mean $\mathrm{R}^{2}$ for all the periods is $70.35 \%$, indicating that about $70 \%$ of the excess returns of UK domestic investment trusts can be explained by the FTSE 350 Index. However, the average minimum value of $22.57 \%$ indicates, that there were some funds in the sample, where the FTSE 350 Index had a weak explanatory power for their excess returns.

The main objective of regressing each funds excess return on the four factors of Carhart's model is to obtain the intercepts (Alphas) for each fund. The Alpha represents the abnormal returns of the fund and is the main measure of performance used in this study. Table 5 reports the average coefficient values and the significance of the Carhart's Four-Factor model. 


\section{Table 5: Carhart Four-Factor Coefficient Regression Results}

The table below reports the average coefficient values obtained from regressing the excess returns of 119 UK investment trusts on the Carhart's Four-Factor model for each of the six sub-periods from January 1997 to December 2014 in the following way:

$$
R_{t}-R_{f}=\alpha_{t}+\beta_{1} R M R F_{t}+\beta_{2} S M B_{t}+\beta_{3} H M L_{t}+\beta_{4} M O M_{t}+\varepsilon_{t}
$$

The Alpha $\alpha_{t}$ represents the abnormal fund return based on the model above. RMRF, SMB, HML and MOM are the four factors of Carharts Four-Factor model.

The $\mathrm{R}^{2}$ values at the bottom of the table represent the average $\mathrm{R}^{2}$ for each of the six sub-periods.

\begin{tabular}{|c|c|c|c|c|c|c|}
\hline & \multicolumn{6}{|c|}{ Sub-periods } \\
\hline & $\begin{array}{c}1997- \\
1999\end{array}$ & $\begin{array}{c}2000- \\
2002\end{array}$ & $\begin{array}{c}2003- \\
2005\end{array}$ & $\begin{array}{l}2006- \\
2008\end{array}$ & $\begin{array}{c}2009- \\
2011\end{array}$ & $\begin{array}{c}2012- \\
2014\end{array}$ \\
\hline $\begin{array}{c}\text { Intercept }(\boldsymbol{\alpha}) \\
\text { Coefficient }\end{array}$ & $-0.0023 *$ & $0.0045 *$ & -0.0003 & 0.0005 & $-0.0015 * *$ & -0.0006 \\
\hline $\begin{array}{c}\text { RMRF } \\
\text { Coefficient }\end{array}$ & $0.9666^{*}$ & $0.8331 *$ & $0.7779 *$ & $0.9004 *$ & $0.8905 *$ & $0.8366 *$ \\
\hline $\begin{array}{c}\text { SMB } \\
\text { Coefficient }\end{array}$ & $0.3139 *$ & $0.3644 *$ & $0.4462 *$ & $0.1382 *$ & $0.1045 *$ & $0.2968 *$ \\
\hline $\begin{array}{c}\text { HML } \\
\text { Coefficient }\end{array}$ & $0.0394 * *$ & $-0.2088 *$ & $0.151 *$ & $-0.075 *$ & $-0.1778 *$ & $-0.2350 *$ \\
\hline $\begin{array}{c}\text { MOM } \\
\text { Coefficient }\end{array}$ & $0.0971 *$ & $-0.078 *$ & $0.0419 *$ & $-0.0967 *$ & -0.0038 & $-0.0713 *$ \\
\hline Average $\mathbf{R}^{\mathbf{2}}$ & 0.6935 & 0.7472 & 0.6908 & 0.694 & 0.7192 & 0.6765 \\
\hline
\end{tabular}

\footnotetext{
* indicates a significance at $1 \%$ level

** indicates a significance at $5 \%$ level

$* * *$ indicates a significance at $10 \%$ level
}

As can be seen from the table above, most of the obtained coefficients are significant at $1 \%$ level of significance indicating that the factors included in the model explain the excess returns of the funds in our sample. A positive SMB coefficient indicates that the fund returns are more aligned with those of small-cap stocks rather than large-cap stocks of the FTSE 350 index, while a positive HML coefficient indicates, that the fund returns are more aligned with those of value, rather than growth stocks. A high MOM factor indicates that the funds are mostly invested in high momentum stocks rather than low momentum stocks. Table 5 summarizes the descriptive statistics for the Alphas (intercepts) obtained from the Carhart's Four Factor regression models for each of the six sub-periods. 
The table below shows the descriptive statistics of the Alpha (intercept) values obtained from regressing the excess returns of 119 UK investment trusts on Carhart's Four-Factor model over the period from January 1997 to December 2014 in the following way:

$R_{t}-R_{f}=\alpha_{t}+\beta_{1} R M R F_{t}+\beta_{2} S M B_{t}+\beta_{3} H M L_{t}+\beta_{4} M O M_{t}+\varepsilon_{t}$

The Alpha $\alpha_{i}$ represents the abnormal fund return based on the model above. It is a measure of the fund manager's stock selection ability. The values at the bottom of the table represent the average across all six subperiods.

\begin{tabular}{|c|c|c|c|c|c|c|c|}
\hline Variable & Period & $\begin{array}{c}\text { Mean } \\
\text { abnormal } \\
\text { return } \\
(\%)\end{array}$ & $\begin{array}{l}\text { Median } \\
\text { abnormal } \\
\text { return } \\
(\%)\end{array}$ & $\begin{array}{c}\text { Minimum } \\
\text { abnormal } \\
\text { return } \\
(\%)\end{array}$ & $\begin{array}{c}\text { Maximum } \\
\text { abnormal } \\
\text { return } \\
(\%)\end{array}$ & $\begin{array}{c}\text { Standard } \\
\text { Deviation } \\
(\%)\end{array}$ & No of Obs. \\
\hline \multirow{6}{*}{$\begin{array}{c}\text { Alpha } \\
\text { (abnormal } \\
\text { return) }\end{array}$} & $\begin{array}{c}1997- \\
1999\end{array}$ & -0.234 & -0.278 & -3.231 & 3.818 & 0.758 & 119 \\
\hline & $\begin{array}{c}2000- \\
2002\end{array}$ & 0.449 & 0.203 & -4.876 & 8.481 & 1.455 & 119 \\
\hline & $\begin{array}{c}2003- \\
2005\end{array}$ & -0.035 & -0.099 & -3.416 & 2.674 & 0.766 & 119 \\
\hline & $\begin{array}{c}2006- \\
2008\end{array}$ & 0.055 & 0.132 & -2.919 & 1.346 & 0.646 & 119 \\
\hline & $\begin{array}{c}2009- \\
2011 \\
\end{array}$ & -0.149 & -0.170 & -2.092 & 1.357 & 0.620 & 119 \\
\hline & $\begin{array}{c}2012- \\
2014\end{array}$ & -0.057 & -0.090 & -2.111 & 2.755 & 0.541 & 119 \\
\hline Average & $\begin{array}{c}1997- \\
2014\end{array}$ & 0.004 & -0.05 & -3.108 & 3.405 & 0.798 & 714 \\
\hline
\end{tabular}

The Alpha represents the abnormal returns, which were calculated with Carhart's Four-Factor model. A positive Alpha indicates that the fund generates abnormal returns above the FTSE 350 benchmark after controlling for market returns, SMB, HML and momentum factors, whereas a negative Alpha indicates that the fund generates negative abnormal returns below the FTSE 350 benchmark. The descriptive result indicates that the mean Alphas of UK investment trusts generate negative abnormal returns in four out of six sub-periods. However, the fund managers are only able to generate an average abnormal return of $0.004 \%$ across the whole investigation period. The average median of $-0.05 \%$ indicates that funds rather underperform. The average standard deviation of $0.798 \%$ indicates that there is dispersion among the abnormal fund returns, meaning that some funds underperform, while other funds outperform. However, as can be seen in Table 4, the obtained Alphas are insignificant for three out of six sub-periods and are also insignificant when looking at the whole time period from January 1997 to December 2014. Thus the null hypothesis is accepted, that UK closed-end investment trusts do not generate abnormal returns above those of the FTSE 350 benchmark. 


\section{Persistence Results}

To test the persistence in performance of 119 UK investment trusts, the 18-year evaluation period from January 1997 to December 2014 is divided into six non-overlapping three year sub-periods. Persistence is measured by separating the funds and checking for the correlation of winners in each of the sub-periods using Pearson's Correlation coefficient and OLS regression. The Pearson's Correlation Coefficient is used in order to investigate if there is a correlation between the abnormal fund returns of the prior period with the following period. Table 7 summarizes the results for each sub-period pair.

\section{Table 7: Pearson's Correlation Coefficient Results}

The table below summarises the results of the Person's Correlation test for winning funds of each sub-period of the 119 UK domestic investment trusts sample over six non-overlapping three-year periods from January 1997 to December 2014.

The period pair numbers represent the investigated sub-periods. The pair numbers represent the following periods: 1997-1999 (sub-period 1); 2000- 2002 (sub-period 2); 2003 - 2005 (sub-period 3); 2006 - 2008 (subperiod 4); 2009 -2011 (sub-period 5) and 2012 -2014 (sub-period 6).

\begin{tabular}{c|c|c|c|c|c} 
Period pair & $\begin{array}{c}\text { Sub-period } \\
\mathbf{1 \& 2}\end{array}$ & $\begin{array}{c}\text { Sub-period } \\
\mathbf{2 \& 3}\end{array}$ & $\begin{array}{c}\text { Sub-period } \\
\mathbf{3 \& 4}\end{array}$ & $\begin{array}{c}\text { Sub-period } \\
\mathbf{4 \$ 5}\end{array}$ & $\begin{array}{c}\text { Sub-period } \\
\mathbf{5 \& 6}\end{array}$ \\
\hline $\begin{array}{c}\text { Correlation } \\
\text { Coefficient }\end{array}$ & $-0.545^{*}$ & 0.002 & $-0.495^{*}$ & $0.205^{* * *}$ & -0.149 \\
\hline $\begin{array}{c}\text { Number of } \\
\text { 'Winning' } \\
\text { funds }\end{array}$ & 28 & 75 & 49 & 72 & 42 \\
\hline
\end{tabular}

* indicates a significance at $1 \%$ level

$* * *$ indicates a significance at $10 \%$ level

Results of the Pearson's Correlation test show some significant persistence in performance, with negative correlations in sub-periods $1 \& 2$, and $3 \& 4$ with coefficients of -0.545 and 0.485 at $1 \%$ level respectively but with no consistent pattern. However sub-period $4 \& 5$ is significant and positive with a coefficient of 0.205 at $10 \%$ level indicating a reversal in performance from one period to the following period. The highest positive coefficient is 0.205 at $10 \%$ level of significance at sub-period 4 and 5 and the lowest is -0.545 at $1 \%$ level of significance at sub-period 1 and 2 which overall indicates that there is little persistence in fund performance. Thus concluding, that there is no evidence of persistence in performance of the UK domestic investment trusts. 
We further use the OLS to evaluate, if prior performance can be used as a predictor of future performance. The following periods alphas (intercepts) are used as the dependent variable and the prior periods intercepts as the independent variable. Table 8 summarises the results from the OLS regressions.

\section{Table 8: Ordinary Least Square Regression Results}

The table below shows the results of the OLS regression of the funds abnormal returns on their lagged abnormal returns for 119 UK domestic investment trusts over non-overlapping three-year periods from January 1997 to December 2014:

$$
r_{t}=\alpha+\beta r_{t-1}+\varepsilon
$$

where $r_{t}$ represents the abnormal returns of period $t$ and $r_{t-1}$ represent the abnormal returns of period $\mathrm{t}-1$.

The Period pair numbers represent the investigated sub-periods. The pair numbers represent the following periods: 1997-1999 (sub-period 1); 2000- 2002 (sub-period 2); 2003 - 2005 (sub-period 3); 2006 - 2008 (sub-period 4); 2009 -2011 (sub-period 5) and 2012 -2014 (sub-period 6).

\begin{tabular}{|c|c|c|c|c|c|}
\hline Period pair & $\begin{array}{c}\text { Sub-period } \\
1 \& 2 \\
\end{array}$ & $\begin{array}{c}\text { Sub-period } \\
2 \& 3 \\
\end{array}$ & $\begin{array}{c}\text { Sub-period } \\
3 \& 4 \\
\end{array}$ & $\begin{array}{c}\text { Sub-period } \\
4 \& 5 \\
\end{array}$ & $\begin{array}{c}\text { Sub-period } \\
5 \& 6 \\
\end{array}$ \\
\hline $\begin{array}{c}\text { Coefficient } \\
\text { (Beta) }\end{array}$ & -0.524 & -0.085 & 0.037 & 0.163 & 0.048 \\
\hline $\begin{array}{l}p \text {-value of } \\
\text { coefficient }\end{array}$ & 0.003 & 0.08 & 0.636 & 0.065 & 0.56 \\
\hline$R^{2}(\%)$ & 7.46 & 2.59 & 0.19 & 2.88 & 0.3 \\
\hline No. of Obs. & 119 & 119 & 119 & 119 & 119 \\
\hline
\end{tabular}

The result in the table indicate that two out of five sub-period pairs have negative slope coefficients, which indicates a reversal and inconsistent pattern in performance. This is consistent with the results from the Pearson's Correlation test which shows incongruence in the persistence of the performance in the sub-periods. Despite the significance of the results, the low $\mathrm{R}^{2}$ values, which lie between $0.3 \%$ and $7.46 \%$ indicate, that only $0.3 \%$ to $7.46 \%$ of future abnormal returns can be explained by past abnormal returns. Thus, indicating that prior performance cannot be used as an indicator of future performance.

These results support the winner and loser result (Table 2) above which shows incongruence in the persistence of the funds. For example, while sub-periods the percentage of losers high in sub-periods 1, 3, 4 and 5, there are winners' funds in sub-periods 2 and 4. These results 
demonstrate that the persistence of the fund performance is inconsistent and therefore cannot be a reliable measure of future performance.

\section{Result of IFRS and UK investment trust performance}

This section explains result of the influence of the mandatory EU wide adoption of accounting standards on UK domestic investment trust performance. As described earlier, in order to test whether the adoption of IFRS has an influence on the performance of 119 UK investment trusts, we use a modified version of the Carhart Four-Factor model with a dummy variable to capture the effect of the mandatory IFRS adoption over the period January 1997 to December 2014, regressed the excess returns of 119 investment trusts in the sample on the pre and post adoption performance with 2005 as base year. CRISIS is a dummy that captures the effects of the 20072009 financial crisis reaching from the highest point of the FTSE 100 Index in October 2007 to the lowest point in March 2009 (1= from October 2007 to March 2009 and 0 otherwise). Where CRISIS is negative and significant, then we can conclude that it is indeed the effect of regime change. Table 8 presents the regression results rounded to four decimals.

The results of the test show a negative mean coefficient of the dummy variable (AAS) of 0.0020, which implies that on average the EU wide adoption of IFRS has a negative impact of $-0.20 \%$ on excess fund returns. The coefficients range between -0.0265 and 0.0115 with a standard deviation of 0.065 which suggests that the adoption of IFRS has an increasing effect on some funds, and a decreasing effect on others but with an overall negative effect on the UK investment funds. On average, $60 \%$ of the excess fund returns could be explained by the modified Carhart Four-Factor model. The CRISIS dummy is insignificant which suggests that the result is not affected by the financial crisis. 
The table shows the descriptive statistics of the obtained coefficients from 119 regressions of funds excess returns against the modified Carhart Four-Factor model over the period from January 1997 to December 2014 in the following way:

$$
R_{t}-R_{f}=\alpha_{t}+\beta_{1} R M R F_{t}+\beta_{2} S_{M} B_{t}+\beta_{3} H M L_{t}+\beta_{4} M O M_{t}+\beta_{5} A A S_{t}+\beta_{6} \text { CRISIS }_{t}+\varepsilon_{t}
$$

where AAS is the dummy variable for the Adoption of Accounting $\underline{\text { Standards }}(0=$ from January 1997 to December 2004; 1 = from January 2005 to December 2014) . "Crisis" is the dummy to capture the effects of the 2007-2009 financial crisis reaching from the highest point of the FTSE 100 Index in October 2007 to the lowest point in March 2009 (1= from October 2007 to March 2009 and 0 otherwise); all other factors as in Carhart's Four-Factor Model. A positive coefficient implies that the adoption of accounting standards increased the funds excess returns, while a negative coefficient implies the opposite.

\begin{tabular}{|c|c|c|c|c|c|c|c|}
\hline Variable & Period & Mean & Median & Minimum & Maximum & $\begin{array}{l}\text { Standard } \\
\text { Deviation }\end{array}$ & $\begin{array}{l}\text { No of } \\
\text { Obs. }\end{array}$ \\
\hline $\begin{array}{l}\text { Intercept } \\
\text { Coefficient }\end{array}$ & $\begin{array}{l}1997- \\
2014\end{array}$ & $0.001 * *$ & -0.00001 & -0.0138 & 0.0178 & 0.0051 & 119 \\
\hline $\begin{array}{c}\text { RMRF } \\
\text { Coefficient }\end{array}$ & $\begin{array}{l}1997- \\
2014\end{array}$ & $0.8786^{*}$ & 0.9662 & 0.0256 & 1.7547 & 0.3554 & 119 \\
\hline $\begin{array}{c}\text { SMB } \\
\text { Coefficient }\end{array}$ & $\begin{array}{l}1997- \\
2014\end{array}$ & $0.2729 *$ & 0.1645 & -0.1521 & 0.9769 & 0.2942 & 119 \\
\hline $\begin{array}{c}\text { HML } \\
\text { Coefficient }\end{array}$ & $\begin{array}{l}1997- \\
2014\end{array}$ & $-0.1332 *$ & -0.0812 & -1.3013 & 0.3588 & 0.2540 & 119 \\
\hline $\begin{array}{c}\text { MOM } \\
\text { Coefficient }\end{array}$ & $\begin{array}{l}1997- \\
2014\end{array}$ & -0.008 & -0.0111 & -0.203 & 0.1989 & 0.0725 & 119 \\
\hline $\begin{array}{c}\text { AAS } \\
\text { dummy } \\
\text { coefficient }\end{array}$ & $\begin{array}{l}1997- \\
2014\end{array}$ & $-0.0020 *$ & -0.0015 & -0.0265 & 0.0115 & 0.0065 & 119 \\
\hline $\begin{array}{c}\text { Crisis } \\
\text { dummy } \\
\text { Coefficient }\end{array}$ & $\begin{array}{l}1997- \\
2014\end{array}$ & -0.0005 & 0.0007 & -0.0656 & 0.0285 & 0.0129 & 119 \\
\hline$R^{2}$ & $\begin{array}{c}1997- \\
2014 \\
\end{array}$ & 0.601 & 0.7083 & 0.018 & 0.8995 & 0.2513 & 119 \\
\hline
\end{tabular}

* indicates a significance at $1 \%$ level

$* *$ indicates a significance at $5 \%$ level

$* * *$ indicates a significance at $10 \%$ level

The average effect on the funds' excess returns caused by the adoption of accounting standards is $-0.20 \%$ and significant, implying that the adoption of accounting standards made the UK market more efficient but with a decreasing influence on funds' excess returns. 


\section{Robustness check of IFRS adoption on UK investment trust performance}

In the previous section, the excess returns of $119 \mathrm{UK}$ investment trusts were regressed on a modified version of the Carhart Four-Factor model by including IFRS and CRISIS proxies. In order to prove that the result is not just capturing the shift in the regime and not the IFRS impact or affected by the construction procedure, we re-estimated the model using same observations from 1998 until end of 2006, prior to the financial crisis. This is to check if the negative effect persists. The result indicates that the AAS is still negative and significant with a $\mathrm{R}^{2}$ of $62 \%$ and confirms that the negative effect of IFRS on the investment funds returns. Table 10 summarises the results from the robustness test. Hence, the robustness results confirm our previous findings, that IFRS adoption has a negative impact on performance of investment trust returns.

\section{Table 10: Robustness Tests Results}

The table shows the results of the robustness test of the proxy for the adoption of IFRS from 119 regressions of funds returns over the period from January 1997 to December 2006 in the following way:

$$
R_{t}-R_{f}=\alpha_{t}+\beta_{1} R M R F_{t}+\beta_{2} S M B_{t}+\beta_{3} H M L_{t}+\beta_{4} M O M_{t}+\beta_{5} A A S_{t}+\varepsilon_{t}
$$

where AAS is the dummy variable for the Adoption of $\underline{\text { Accounting }} \underline{\text { Standards }}(0=$ from January 1997 to December 2004; 1 = from January 2005 to December 2006); all other factors as in Market Model.

\begin{tabular}{|c|c|c|c|c|c|c|c|}
\hline Variable & Period & Mean & Median & Minimum & Maximum & $\begin{array}{l}\text { Standard } \\
\text { Deviation }\end{array}$ & No. of Obs. \\
\hline $\begin{array}{l}\text { Intercept } \\
\text { Coefficient }\end{array}$ & $\begin{array}{l}1997- \\
2006\end{array}$ & 0.0007 & -0.0006 & -0.018 & 0.0169 & 0.0055 & 119 \\
\hline $\begin{array}{c}\mathbf{R M} \\
\text { Coefficient }\end{array}$ & $\begin{array}{c}1997- \\
2006\end{array}$ & $0.8817^{*}$ & 0.9692 & -0.0641 & 1.9263 & 0.3530 & 119 \\
\hline $\begin{array}{c}\text { SMB } \\
\text { Coefficient }\end{array}$ & $\begin{array}{c}1997- \\
2006\end{array}$ & $0.3853^{*}$ & 0.2937 & -0.052 & 1.3139 & 0.3321 & 119 \\
\hline $\begin{array}{c}\text { HML } \\
\text { Coefficient }\end{array}$ & $\begin{array}{c}1997- \\
2006\end{array}$ & $-0.0908^{*}$ & -0.0562 & -1.3928 & 0.3676 & 0.2832 & 119 \\
\hline $\begin{array}{c}\text { MOM } \\
\text { Coefficient }\end{array}$ & $\begin{array}{c}1997- \\
2006\end{array}$ & -0.0061 & 0.0007 & -0.2521 & 0.3004 & 0.089 & 119 \\
\hline $\begin{array}{c}\text { AAS } \\
\text { dummy } \\
\text { coefficient }\end{array}$ & $\begin{array}{c}1997- \\
2006\end{array}$ & $-0.0017 * *$ & -0.0005 & -0.0352 & 0.0122 & 0.0078 & 119 \\
\hline$R^{2}$ & $\begin{array}{c}1997- \\
2006\end{array}$ & 0.6242 & 0.7242 & 0.0395 & 0.8919 & 0.2478 & 119 \\
\hline
\end{tabular}




\section{Summary of findings}

The results of the alphas for three out of our six sub-periods and the model are insignificant. Thus, the null hypothesis is accepted, concluding that UK domestic investment trusts do not generate significant abnormal returns above the benchmark. We control for market return, SMB, HML and Momentum factors. These findings support Bal and Leger (1996) perform analysis of UK investment trusts from 1975 to 1993 and find that on average funds underperformed compared to the market portfolio. These results are also similar to those obtained in US studies on open-end fund market (Zhang, 1999). Therefore, even though the results of this study suggest that the US and UK fund markets share characteristics, our study is based on a more recent sample from 1997-2014.

The second objective of this study is to test for any persistence in fund performance. The analysis is conducted by forming five sub-period pairs out of our six three-year sub-periods. Persistence in performance is then analysed between each sub-period paired. The first persistence analysis is conducted by calculating the Pearson's Correlation coefficient between each of the six sub-period pairs. The results show negative correlations with no consistent pattern between the sub-periods suggesting a reversal in performance between sub-period. There is no evidence of any significant persistence in performance over the evaluation period. The second persistence analysis is conducted using the OLS regression to evaluate if prior performance can be used to predict future performance. The regression is constructed by using the preceding period's alphas (intercepts) as variables. The result indicates that two of the obtained coefficients are negative, supporting the results from the Pearson's Correlation Coefficient test that the fund performance is incongruent over the sub-periods. Although one of the obtained correlation coefficients is significant at $1 \%$ level of significance and two are significant at $10 \%$ level, the overall model has very low $\mathrm{R}^{2}$ values between $0.3 \%$ and $7.46 \%$. In summary, we find no evidence of persistence in the performance of UK investment trusts and that prior performance of UK investment trusts is not a good predictor of their future performance.

The third objective of our study is to analyse if the EU wide mandatory adoption of the International Financial Reporting Standards (IFRS) in January 2005 had an influence on the performance of UK investment trusts. The result of the analysis shows a negative mean coefficient of AAS variable which implies that on average, the EU wide adoption of IFRS had a decreasing impact on the excess returns of UK domestic investment trusts. The negative 
impact obtained is not caused by the financial crisis which preceded the IFRS adoption. The obtained mean $\mathrm{R}^{2}$ value of the regressions implies that on average $60 \%$ of excess fund returns is explained by the modified Carhart Four-Factor regression model. Our robustness test result confirms our findings that on average the effect of the adoption of IFRS on funds' excess returns is significantly negative.

We conclude that whilst the adoption of IFRS seems to have improved the efficiency of the UK market, it resulted in decreasing the funds excess returns. To the best of our knowledge, this is the first study to investigate the effect of IFRS on closed-end fund. Other studies (Byard et al., 2011; Pope and McLeay, 2011; and Horton et al, 2013), have focused on the effect of the mandatory adoption of IFRS on financial analysts' information environment. These studies suggest that forecast errors as well as forecast dispersion decreased and the overall information environment improved in countries such as the United Kingdom after the adoption of IFRS. Since fund managers use analyst reports to make investment decisions their findings corroborate our finding on the increased efficiency of the market following the IFRS adoption.

\section{Conclusion}

Our paper focuses on three main objectives. First, it measures the performance of UK closedend funds with UK domestic equity focus. The second is to examine if there is any persistence in performance of those funds and the third, examine whether the EU wide adoption of IFRS has any influence on the performance of those funds. Our study focuses on investment trusts which are incorporated in the United Kingdom and have a domestic equity investment focus from January 1997 to December 2014 and, divided into six non-overlapping three-year periods.

Our study extends the existing literature on closed-end funds by examining the performance of UK domestic investment trusts over a more recent time period. Furthermore, our paper makes significant contribution to the extant literature on the mandatory IFRS adoption in the UK by investigating the impact of the adoption on the performance of UK domestic investment trusts. The result indicates that on average, the adoption of IFRS has a decreasing significant impact on the excess returns of the UK domestic investment funds. This is further corroborated by the increased percentage of loser funds following the sub-periods after the 2005 mandatory adoption. 
The Carhart (1997) Four-Factor model is used to determine if UK investment trusts generate abnormal returns, while the Pearson Correlation Coefficient and the OLS regression are used to test if the performance of UK investment trusts is persistent. The results provide evidence that in the period from January 1997 to December 2014, the UK investment trusts did not generate significant positive abnormal returns. The results on the persistence of fund performance show no consistent pattern of persistence and suggesting that investment trust performance is not persistent and that prior investment trust performance should not be used as an indicator for future performance. The policy implication is that investors should not make investment decisions based on the prior performance of a fund. This is because the performance of the UK investment funds market is incongruent as it has no consistent pattern. The findings also give some evidence of Efficient Market Hypothesis in the UK investment funds market as the adoption of the IFRS seems to have made the markets more efficient and therefore harder to generate abnormal returns.

\section{References}

Agarwal, V.and Naik, N. (2000) Multi-Period Performance Persistence Analysis of Hedge Funds. Journal of Financial and Quantitative Analysis, VOL. 35, NO. 3, pp. 327-342.

Allen, D. E. and Tan, M. L. (1999) "A Test of the Persistence in the Performance of UK Managed Funds", Journal of Business Finance \& Accounting, VOL. 26 NO.5, pp. 559-593.

Anderson, S. C., Coleman, B. J., Gropper, D., and Sunquist, H. (1996) "A Comparison of the Performance of Open and Close-End Investment Companies," Journal of Finance, VOL. 20 NO.3, pp. 3-11.

Angelidis, T., Giamouridis, D. and Tessaromatis, N. (2013) "Revisiting mutual fund performance evaluation”, Journal of Banking and Finance, VOL.37, pp.1759-1776

Armstrong, C. S., Barth, M. E., Jagolinzer, A. D. and Riedl, E. J. (2010), "Market reaction to the adoption of IFRS in Europe", The Accounting Review, VOL. 85 NO. 1, pp. 31-61.

Bal, Y. and Leger, L. A. (1996) "The Performance of UK Investment Trusts", The Service Industries Journal, VOL. 16 NO. 1, pp. 67-81.

Ball, R. (2006), "International Financial Reporting Standards (IFRS): pros and cons for investors", Accounting and Business Research, VOL. 36 NO. 1, pp. 5-27. 
Bangassa, K., Su, C. and Joseph, N.L. (2012) "Selectivity and timing performance of UK investment trusts", Journal of International Financial Markets, Institutions and Money, VOL. 22 NO. 5, pp. 1149-1175.

Berk, J.B. and Green, R.C. (2004) "Mutual fund flows and performance in rational markets", Journal of Political Economy, VOL. 112 NO. 6, pp. 1269-1295.

Bers, M. K.; and Madura, J. (2000) "Performance Persistence of Closed-End Funds", Financial Review, VOL. 35 NO.3, pp. 33-53.

Bielstein, M.T., Munter, P.H., Schinas, W.J. (2007) How the IFRS movement will affect financial reporting in the US. New York, KPMG Department of Public Practice, Defining Issues Series.

Bowman, R. G. (1983) Understanding and conducting event studies. Journal of Business Finance \& Accounting, VOL. 10 NO.4, pp. 561-584.

Brown, S. J, and Warner, J. B. (1985) Using daily stock returns: The case of event studies. Journal of financial economics, VOL. 14 NO. 1, pp. 3-31.

Brüggemann, U., Daske, H., Homburg, C. and Pope, P. (2010), "How do individual investors react to global IFRS adoption?", SSRN Electronic Journal, pp. 1-48.

Buchner, A., Mohamed, A. and Schwienbacher, A. (2016) Does risk explain persistence in private equity performance? Journal of Corporate Finance, VOL. 39, 18-35

Byard, D., Li, Y. and Yu, Y. (2011), "The effect of mandatory IFRS adoption on financial analysts' information environment", Journal of Accounting Research, VOL. 49 NO. 1, pp. 6996.

Carhart, M.M. (1997) “On Persistence in Mutual Fund Performance”, Journal of Finance, VOL. 52 NO.1, pp. 57-82.

Covrig, V.M., Defond, M.L. and Hung, M. (2007) Home Bias, Foreign Mutual Fund Holdings, and the Voluntary Adoption of International Accounting Standards. Journal of Accounting Research VOL. 45, NO 1, pp. 41-70

Daniel, K., Grinblatt, M., Titman, S. and Wermers, R. (1997), "Measuring Mutual Fund Performance with Characteristic-Based Benchmarks", Journal of Finance, VOL. 52 NO. 3, pp. $1035-1058$.

DeFond, M., Hu, X., Hung, M. and Li, S. (2011) The impact of mandatory IFRS adoption on foreign mutual fund ownership: The role of comparability. Journal of Accounting and Economics VOL. 51, NO 3, pp. 240-258

Doukakis, L.C. (2010) The persistence of earnings and earnings components after the adoption of IFRS. Managerial Finance, Vol. 36 No. 11, pp.969-980 
Eling, M. (2009) Does Hedge Fund Performance Persist? Overview and New Empirical Evidence. European Financial Management, VOL. 15, NO. 2, pp.362-401.

Elton, E. J., Gruber, M. J. and Blake, C. R. (1996) "Survivorship Bias and Mutual Fund Performance", Review of Finance Studies, VOL. 9 NO. 4, pp. 1097-1120.

Fama, E. F. (1970), "Efficient Capital Markets: A Review of Theory and Empirical Work", Journal of Finance, VOL. 25 NO.2, pp. 383-417.

Fama, E.F., and French, K. R. (2010) "Luck versus Skill in the Cross-Section of Mutual Fund Returns" The Journal of Finance, VOL. 65 NO. 5, pp. 1915.

Florou, A. and Pope, P. F. (2012), "Mandatory IFRS adoption and institutional investment decisions", The Accounting Review, VOL. 87 NO.6, pp. 1993-2025.

Fuller, K., Netter, J., \& Stegemoller, M. (2002) 'What do returns to acquiring firms tell us? Evidence from firms that make many acquisitions'. Journal of Finance 57 (4), 1763-1793.

Goetzmann, W. N., and Ibbotson, R. G. (1994) "Do winners repeat?" The Journal of Portfolio Management, VOL. 20 NO. 2, pp. 9-18.

Gordon, L.A., Loeb, M.P., \& Zhu,W. (2012). “The impact of IFRS adoption on foreign direct investment",. Journal of Accounting and Public Policy, VOL. 31 NO 4, pp.374-398.

Gregory, M., Tharyan, K. and Christidis, L. (2013) "Constructing and Testing Alternative Versions of the Fama-French and Carhart Models in the UK", Journal of Business Finance \& Accounting, VOL. 40 NO. 1/2, pp. 172-214.

Grinblatt, M. and Titman, S. (1992) “The Persistence of Mutual Fund Performance”, Journal of Finance, VOL. 47 NO. 5, pp. 1977-1984.

Grinblatt, M., Titman, S. and Wermers, R. (1995) "Momentum investment strategies, portfolio performance and herding: a study of mutual fund behaviour." American Economic Review, VOL. 85 NO. 5, pp. 1088-1105.

Grossman, S. J. and Stiglitz, J. E. (1980) "On the Impossibility of Informationally Efficient Markets", The American Economic Review, VOL. 70 NO. 3, pp. 393-408.

Gruber, M. J. (1996), "Another Puzzle: The Growth in Actively Managed Mutual Funds", Journal of Finance, VOL. 51 NO.3, pp. 783-810.

Gupta, R. and Jithendranathan, T. (2012) "Fund flows and past performance in Australian managed funds", Accounting Research Journal, Vol. 25 NO. 2, pp.131 - 157

Hendricks, D., Patel, J. and Zeckhauser, R. (1993) "Hot Hands in Mutual Funds: Short-Run Persistence of Relative Performance, 1974-1988”, The Journal of Finance, VOL. 48 NO.1, pp. 93-130. 
Henriksson, R.D. (1984) "Market Timing and Mutual Fund Performance: An Empirical Investigation", Journal of Business, VOL. 57 NO. 1, pp. 73-96.

Henriksson, R. D. and Merton, R. C. (1981) "On Market Timing and Investment Performance. II. Statistical Procedures for Evaluating Forecasting Skills", Journal of Business, VOL. 54 NO.4, pp. 513-533.

Henry, D. (2008) Global accounting rules: simpler, yes. But better? Business Week, September 4

Ho, L.J., Liao, Q. and Taylor, M. (2015) "Real and Accrual-Based Earnings Management in the Pre- and Post-IFRS Periods: Evidence from China.' Journal of International Financial Management and Accounting VOL. 26, pp. 294-335

Hooper, K., David, H., Su, R. and Dani, A.C.F. (2006) "Persistence in Mutual Fund Returns: New Zealand Evidence", Accounting Research Journal, VOL. 19 NO 2, pp.105 $-121$

Horton, J., Serafeim, G. and Serafeim, I. (2013), "Does Mandatory IFRS Adoption Improve the Information Environment?", Contemporary Accounting Research, VOL. 30 NO.1, pp. 388423.

Hung, M. (2001) "Information and Trading Risks in Global Investing: An Empirical Analysis of Research Location and Pacific Rim Mutual Fund Performance", Journal of International Financial Management and Accounting, VOL.12 NO.1, pp.1-23

International Accounting Standard Board (2008). Exposure draft of an improved conceptual framework for financial reporting. London, International Accounting Standards Board.

Jegadeesh, N. and Titman, S. (1993) "Returns to buying Winners and Selling Losers: Implications for Stock Market Efficiency," Journal of Finance, VOL. 48 NO 1, pp. 65-91.

Jensen, M.C. (1968) "The Performance of Mutual Funds in the Period 1945-1964", The Journal of Finance, VO.L 23 NO. 2, pp. 389-416.

Jiao, T., Koning, M., Mertens, G., and Roosenboom, P. (2012) Mandatory IFRS adoption and its impact on analysts' forecasts. International Review of Financial Analysis VOL. 21, pp. $56-63$

Judge, W., Li, S., \& Pinsker, R. (2010). "National adoption of international accounting standards: An international perspective", Corporate Governance: An International Review, VOL. 18 NO 3, 161-174.

Kontonikas, A., Macdonald, R. and Saggu, A. (2013) Stock market reaction to fed funds rate surprises: State dependence and the financial crisis. Journal of Banking and Finance VOL. 37, pp.4025-4037. 
Kryzanowski, L. and Mohebshahedin, M. (2016) "Board governance, monetary interest, and closed-end fund performance", Journal of Corporate Finance VOL. 38, pp. 196-217

Landsman, W.R., Maydew, E.L. and Thornock, J.R. (2012)' The information content of annual earnings announcements and mandatory adoption of IFRS. Journal of Accounting and Economics, VOL. 53, NO. 1-2, pp. 34-54

Leger, L. A. (1997) "UK Investment Trusts: Performance, Timing and Selectivity", Applied Economic Letters, VOL. 4 NO. 4, pp. 207-210.

Leuz, C., Nanda, D., Wysocki, P.(2003) Earnings management and investors protection: an international comparison. Journal of Financial Economics, 69, pp. 505-527.

Malkiel, B. G. (1995) "Returns from Investing in Equity Mutual Funds 1971 to 1991", The Journal of Finance, VOL. 50 NO.2, pp. 549-572.

Malkiel, B. and Saha, A. (2005) Hedge Funds: Risk and Return. Financial Analysts Journal, VOL. 61, NO 6, pp. 80-88.

Nnadi, M. and Soobaroyen, T. (2015) International Financial Reporting Standards and Foreign Direct Investment: The Case of Africa. Advances in Accounting, incorporating Advances in International Accounting, VOL. 31 NO.2, pp. 228-238.

Nnadi, M.A, (2015) "Stock market Reaction, Financial Reporting Quality and International Financial Reporting Standards (IFRS) Convergence of Listed Firms in China", Global Business and Economic Review VOL. 14 NO 7,pp. 399-415

Phelps, S. and Detzel, L. (1997) "The non-persistence of mutual fund performance", Quarterly Journal of Business and Economics, VOL. 36 NO. 2, pp. 55-69.

Pope, P. F. and McLeay, S. J. (2011), "The European IFRS experiment: Objectives, research challenges and some early evidence", Accounting and Business Research, VOL. 41 NO.3, pp. 233-266.

Serra, A.P. (2002) 'Event Study tests: a brief survey’, Working papers da FEP.117, pp.1-10.

Treynor, J. L. and Mazuy, K. K. (1966) "Can Mutual Funds Outguess the Market", Harvard Business Review, VOL. 44 NO.4, pp. 131-136.

Wermers, R. (2000) "Mutual Fund Performance: An Empirical Decomposition into StockPicking Talent, Style, Transactions Costs, and Expenses", The Journal of Finance, VOL. 55 NO.4, pp.1655-1659.

Zheng, L. (1999) “Is Money Smart? A Study of Mutual Fund Investors' Fund Selection Ability", The Journal of Finance, VOL. 54 NO.3, pp. 901-933. 